\title{
高速作動パルブ方式衝撃波風洞およひ高速マスサンプリング プローブを用いた超音速気体湜合過程に関する実験*1
}

\section{An Experimental Study of Supersonic Mixing Process by Using Shock Tunnel Using Quick-Action Valves and Quick-Mass-Sampling Probe Technique}

\author{
畠山雅規*2 船 曳 勝 之*3 \\ Masahiro HATAKEYAMA, Katsushi FUNABIKI \\ 安部 隆 $\pm^{* 3}$ \\ and Takashi ABE
}

\begin{abstract}
Key Words : High Enthalpy Flows, Shock Tunnel, Supersonic Mixing Process, Schlieren Method, Mass-Sampling Probe
\end{abstract}

\begin{abstract}
In order to examine the supersonic mixing process in a high enthalpy supersonic flow, the shock tunnel using the quick-action valves has been developed and confirmed their operation. The present shock tunnel enables to make a high enthalpy flow without contamination in high reproducibility by easy operation. The nozzle is designed to make parallel supersonic flows which are comprised of high-enthalpy air stream and helium stream. Mach number of air and helium flow are 3.4 and 4.2 , respectively. The structure of mixing region of parallel supersonic flows thus obtained was examined by means of the mass-sampling probe which enables one to examine directly the concentration ration of the mixture gases. The measurement shows that the mixing region almost agrees with the region observed by Schlieren photograph.
\end{abstract}

\section{1. まえがき}

スクラムジェットや強制混合形 $\mathrm{CO}_{2}$ ガスダイナミ ックレーザにおける研究分野では，それらの性能と超 音速気体流相互の気体混合過程との関連性について, 大きな興味がもたれている1 体研究においては， そうした高エンタルピの超音速流における，気体混合 問題を対象とした研究を行うことを目指し，その第一 段階として，高速作動バルブ方式による徨撃波風洞お

\footnotetext{
*1 平成元年 2 月 17 日原稿受理

*2 武继工業大学大学院

*3 宇宙科学研究所
}

よび高速サンプリングバルブ方式を用いた高速マスサ ンプリングプローブを製作し，それらの動作特性の確 認を行った結果について述べる．また，一例として， 超音速気体混合流の可視化実験と高速マスサンプリン グプローブによる気体の濃度分布測定実験を行い，そ れらの比較を行ったので, 併せて報告を行う．

衝擊波風洞は，高エンタルピ流れの基礎実験装置と して広く用いられている. 通常の衝撃波風洞では, 街 撃波生成に破膜による方式が用いられている。また， 試料気体と真空槽の分離にも隔膜が使用されている. 本実験で製作された衝擊波風洞は, 自由ピストン高速 バルブ方式による衝撃波生成機構を有している。さ に，試料気体と真空槽の分離には，高速作動ゲートバ ルブ方式が考案され，隔膜の代わりに使用されてい る.自由ピストン高速バルブ方式抢よび高速作動ゲー トバルブ方式による衝撃波風洞作動時の主な長所とし ては，(1) 破膜による気流の污染がない，(2) 衝撃 波風洞の繰り返し操作が簡便である, 等が挙げられ る.

従来, 超音速流中における気体の混合過程の研究 は、流れの可視化により行われてきた。これに対し， マスサンプリングプロープ法では ${ }^{2)}$, 混合状態を直接 計測することができ．より詳細な混合過程の研究が可 能である．高速マスサンプリングプローブによる濃度 測定法の長所としては，（1）局所における濃度測定 が可能であり，三次元的な気体の混合流問題において も十分適用できうる.（2）測定系の取扱いが簡単て ある，(3) 原理的には，気体相互の流入数密度の割 合に依存したマスフィルタ（質量分析器）の出力比か 
ら濃度を求めるため, その出力比は圧力, 密度、温度 等の変化に対して鈍感であり，圧縮性効果の高い流れ

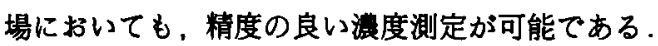

\section{2. 重撃波風洞と的作確認}

2.1 衙慗波風洞 第 1 図に衝擊波風洞の概略図を 示すこの衝撃波風洞は、これまで自由飛行体発射装 置として使用されてきたものを改造したものであ る".

衛撃波風洞は大きく分けて，高圧部，低圧管，ノス ル部そして真空槽から錸成されている。高圧部は，内 径 $210 \mathrm{~mm}$ ，長さ $2.5 \mathrm{~m}$ であり，低圧管は，内径 82 $\mathrm{mm}$, 長さ約 $7.8 \mathrm{~m}$ である. 真空槽は, 内径 $500 \mathrm{~mm}$ で長さ約 $8 \mathrm{~m}$ である. 本衙撃波風洞における設定可 能圧力範囲は, 高圧部では $6.86 \mathrm{MPa}\left(70 \mathrm{kgf} / \mathrm{cm}^{2}\right)$ 以 下，低圧管に封入される試料気体初期圧力は $98 \mathrm{kPa}$ $\left(1 \mathrm{kgf} / \mathrm{cm}^{2}\right)$ 以下である. 真空槽は, 油回転ポンプ. メカニカルブースタポンプ、そして油拡散ポンプが接 続されており，最高真空度 $1.3 \times 10^{-3} \mathrm{~Pa}\left(10^{-5}\right.$ torr $)$ ま て使用可能である。なお，真空槽耐圧力の制限によ $\eta$, 通常は, 高圧部圧力は $1.96 \mathrm{MPa}\left(20 \mathrm{kgf} / \mathrm{cm}^{2}\right)$ 以 下で使用される、衝擊波風洞の動作は次のようであ る. 低圧管管端で衝擊波が反射し，貯気槽状態が形成 される，貯気槽状態にある気体は，低圧管下流に設け られた高速作動ゲートバルブおよび断面変換部を経 て、二次元くさび形ノスルへと導かれる. 低圧管下流 に扔ける断面積は，段階的に小さくなり，ノスルスロ

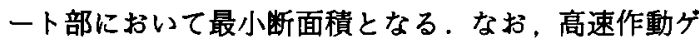
一トバルブを使用しない場合には，隔膜を使用した動 作ができうるように，隔膜設置部が設けられている。

ノスルは，二次元くさび形ノスルであり，超音速気 流相互の混合過程の基礎実験に使用されることを考虑 している，反射衝撃波によって加熱，加圧された空気 は，上部の超音速ノズルによって加速される．下部の
超音速ノスルによって，Heが加速される. 二つの超 音速流を分けている分離板部の下流に扔いて，空気と Heの混合が行われる。なお，Heは貯気容器に封入 されており，高速作動ボールバルブを介してノズルに 導入される．空気を噴出するノスルのスロート幅は， $6 \mathrm{~mm}$ であり，He を噴出するノスルのスロート幅梳， $2 \mathrm{~mm}$ である。なお，双方とも，ノズル幅は $100 \mathrm{~mm}$ である。

高速作動ゲートバルブおよび高速作動ボールバルフ の作動メカニスムには, ラック\&ピニオン式の空気ア クチュエータ方式が採用されている。高速作動ダート バルブでは, 開口時間が約 $2 \sim 3 \mathrm{~ms}$ である. 高速作

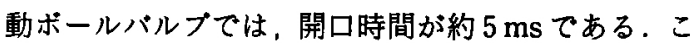
れらの時間は, バルブの開口始動時と終了時における 二つのレーザ光遮断時間間隔から測定された．

超音速気体混合層の生成に対しては，眝気槽生成時 刻と高速作動ゲートバルブ，高速作動ボールバルプの 作動時刻の制御をバルブの開口時刻を見込んで行い. 同期を取る必要がある、マイクロコンピュータを用い て、高圧駆動部の自由ピストン高速バルフ，高速作動 ダートバルブそして高速作動ボールバルブの作動時刻 の制御を行っている.

2.2 動作確諰 貯気槽生成時刻と高速作動ゲート バルブの開口時刻の理想的時間関係は，衝撃波が低圧 管管端で反射する時刻に無限小の時間で高速作動ゲー トバルブが開くことである。しかしながら実際には， バルブは有限の時間で開口し，開口時間は前節で述べ たように2〜3 msである。そして，実験における気 体混合現象の再現性に対して, 貯気槽生成時刻と高速 作動ダートバルフの開口時刻との同期特性が及ほす影 響は，大きいと考えられる，そのため，高速作動げー トバルブの使用に対する必要条件として，次のような 点に留意した．（1）高速作動ゲートバルフの動作の 再現性が良い。（2）高速作動ゲートバルフの開口時

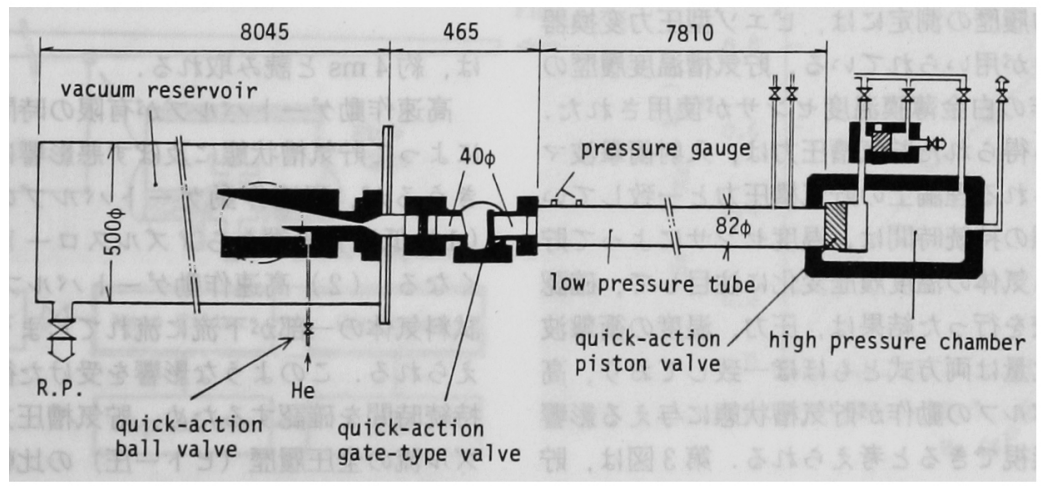

第 1 図 高速作動バルブ方式衙㢣波風洞の概略図 


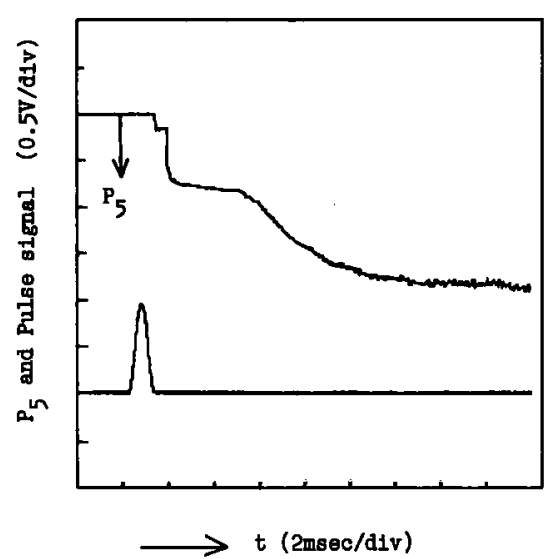

第 2 図 貯気槽生成時刻と高速作娌ゲートバルブの開口時

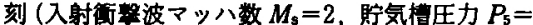
$196 \mathrm{kPa}$ ，貯気槽温度 $T_{5}=750 \mathrm{~K}$ ，初期試料気体 压力 $P_{1}=16 \mathrm{kPa}$, 駆趿圧力 $P_{4}=1.27 \mathrm{MPa}$ ，武料 およひ駆動気体：空気)

間が十分短い，（3）貯気槽生成時刻と高速作動ゲー トバルブ作動時刻の同期特性が良い，作製された高速 作動ゲートバルブでは, バルブ開口時間の再現性は良 好である．上述（3）の同期特性を確認するため，貯気 槽生成時刻と高速作動ゲートバルブおよび高速作動ボ ールバルブの開口時刻との時間関係について, 監視を 行った。バルブの回転軸に取り付けられたフォトイン タラプタによって，開口終了時刻をパルス波形から得 ている．第 2 戝に，一例として，高速作動ダートバル ブに取り付けられたインタラプタのパルス波形と貯気 槽圧力履歴を示す．パルス波形の終わりが，バルブが 開ロした時刻である。

バルブの開口が有限の時間を要することによって， 貯気槽状態と衙擊波風洞の作動時間に与える悪影響が 考えられる、貯気槽状態に与える影響を調へるため高 速作動ゲートバルブを使用した場合と隔膜を使用した 場合の貯気槽圧力，貯気槽温度の履歴の比較を行っ た. 貯気槽圧力履歴の測定には，ピエソ型圧力変換器 (キスラー社製)が用いられている．貯気槽温度履歴の 測定には，自作の白金薄膜温度センサが使用された。 圧力変換器加ら得られた貯気槽圧力は, 入射衙撃波又 ッ八数から得られる理論上の貯気槽圧力と一致してい る，貯気槽状態の持続時間は，温度センサによって貯 気槽状態にある気体の温度履歴変化に注目して，確認 を行った，比較を行った結果は，圧力，温度の衙撃波 通過による変化量は両方式ともほほ一致しており，高 速作動ゲートバルブの動作が貯気槽状態に与える影繁 は，ほとんど無視てきると考えられる，第3図は，貯 気槽圧力と貯気槽温度の履歴てある．貯気槽持続時間

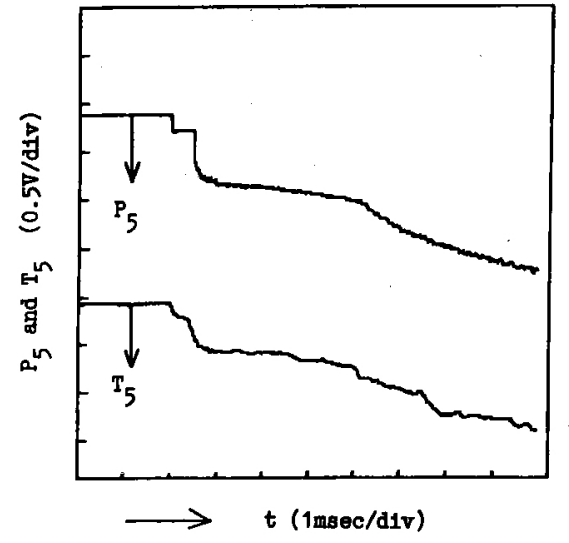

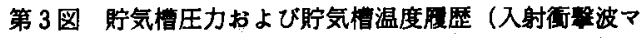
ッ八数 $M_{\mathrm{s}}=2$, 眝気槽圧力 $P_{\mathrm{s}}=196 \mathrm{kPa}$, 眝気棤 温度 $T_{5}=750 \mathrm{~K}$ ，初期試料気体圧力 $P_{1}=16 \mathrm{kPa}$ ， 剾動圧力 $P_{4}=1.27 \mathrm{MPa}$ ，試料および聑動気体： 空気)

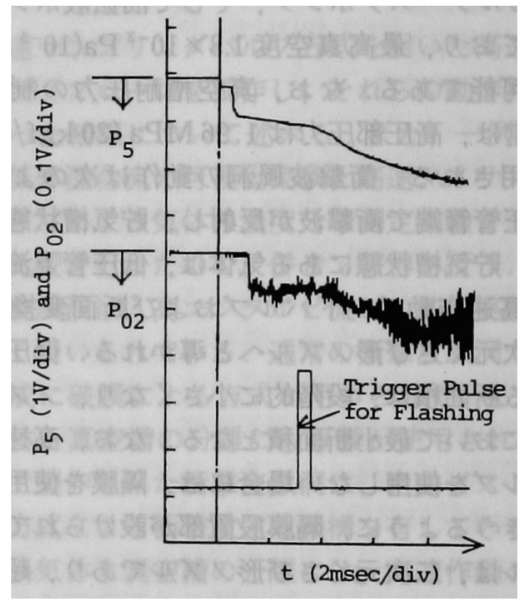

第 4 図 眝気槽圧力および圧カプローブによる全圧履歴 (入射衙整波マッ八数 $M_{3}=2$, 詝気槽压力 $P_{5}=$ $196 \mathrm{kPa}$, 貯気槽温度 $T_{\mathrm{s}}=750 \mathrm{~K}$, 初期試料気体 圧力 $P_{1}=16 \mathrm{kPa}$ ，駆動圧力 $P_{4}=1.27 \mathrm{MPa}$ ，試料 およひ駆動気体：空気）

は，約 $4 \mathrm{~ms}$ と読み取れる．

高速作動ゲートバルブが有限の時間で開口すること によって貯気槽状態に及漅す悪影響はほとんど無視て きうるが，高速作動ダートバルブの設置によって， (1) 低圧管管端からノスルスロートまての距離が長

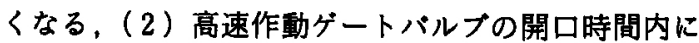
試料気体の一部が下流に流れてしまう，等の損失が考 えられる。このような影響を受けた衞撃波風洞の気流 持続時間を確認するため，貯気槽圧力履歴と超音速ノ スル流の全圧履歴（ピトー圧）の比較を行った．第 4 図に，眝気槽圧力履歴 $\left(P_{5}\right)$ とノスル下流における超 
音速流の全圧展歴（ピトー圧 $P_{02}$ ）を示す．反射衙擊波 による貯気槽状態生成時刻に比へ，超音速流の始動が 約 $1 \mathrm{~ms}$ 遅れている，しかしながら，超音速流の気流 持続時間は約 $3 \mathrm{~ms}$ 確保されている．本実験では，高 速作動ゲートバルプの開口時刻が入射衡撃波が低圧管 管端て反射する直前に行われるため, 試料気体が一部 下流に流出するが，反射街擊波によって加圧加熱され た気体はバルブが開口した状態でノスルに余かれ，第 4 図に示すような全圧履歴が得られ，超音速流始動を 示す压力の立ち上がりも明確にわかる，また，実験で 得られた超音速流の全圧展歴 $\left(P_{02}\right)$ における気流持続 時間内の圧力は、貯気槽圧力と超音速流の全圧 $\left(P_{02}\right)$ との理論上の圧力比から算出した值とほほ一致する.

\section{3. 高速マスサンプリングプローブ}

第 5 図に，高速サンプリングパルブ方式を用いた高 速マスサンプリングプロープの測定系の概略図を示 すフプーブ先端の小孔は内径 $1.5 \mathrm{~mm}$ であり，その 先端の外形はテーパ形状のため内径と一致している. そこから採取された気体は，気流持続時間以外の気体 が高速サンプリングバルブによって採取されることを 防ぐため, 通常, 内容量 $30 l$ 真空容器に導かれる。 真空容器は常に真空ポンプによって排気されており， $1.3 \mathrm{~Pa}\left(10^{-2}\right.$ torr $)$ 程度の真空度を保持している. プロ ープ先端から，約 $140 \mathrm{~mm}$ 下流位固に高速サンプリン グバルブが設けられている．この高速サンプリングバ

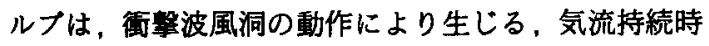
間中にのみ混合気体を採取することを可能にする．高 速サンプリングバルブによって採取された気体は， $0.13 \mathrm{~Pa}\left(10^{-3}\right.$ torr $)$ 程度の真空度にあらかじめ保持さ れているサンプリングリザーバに茅かれた後，4重極 マスフィルタによって灌度分析が行われる．高速サン プリングバルブの機構は，一方向に軸が移動する間
に, 閉 $\rightarrow$ 開 $($ 採取 $) \rightarrow$ 閉の順に状態変化が行われ，気体 のサンプリングが行われる，一連の動作時間，つま り，気体をサンプリングしている時間は，1.8〜2.0 msである。マイクロコンピュータを使用して，マス フィルタ用のコントローラ.デジタルストレージスコ 一プの制御を行い 4 重極マスフィルタからの出力を得 ている. 得られた波形は、全てマイクロコンピュータ によって処理される。

マスフィルタでは， 2 種類 $i, j$ 気体について，それ らの出力比を考えると，

$$
\frac{I_{i}}{I_{j}}=F\left(\frac{n_{i}}{n_{j}}\right)
$$

なる関係がある， $n$ は気体の数密度， $F$ は較正特性 から定まる関数である. 本実験においては， $\mathrm{He}$ と空 気中の $\mathrm{O}_{2}$ を選択し，(1)式において，iとして He， $j$ として $\mathrm{O}_{2}$ に着目して検出を行っている. 空気中の 組成成分比が一定とし, $\mathrm{O}_{2}$ と $\mathrm{He}$ の出力比が, 空気 中の他の成分よりも 4 重極マスフィルタによる検出に 適しているため， $\mathrm{O}_{2}$ が選ばれた。

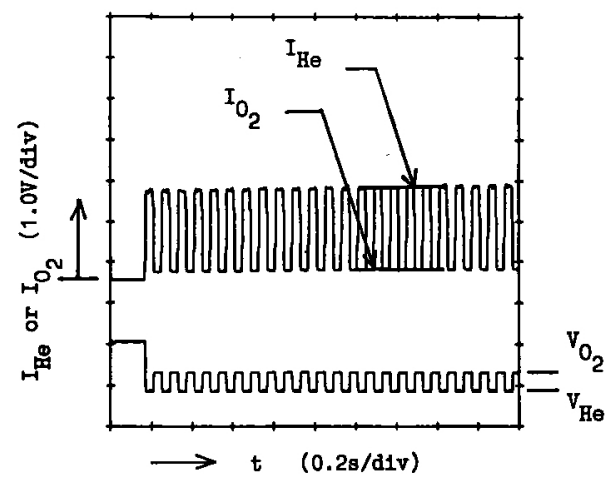

第 6 図較正実医で得られた出力波形

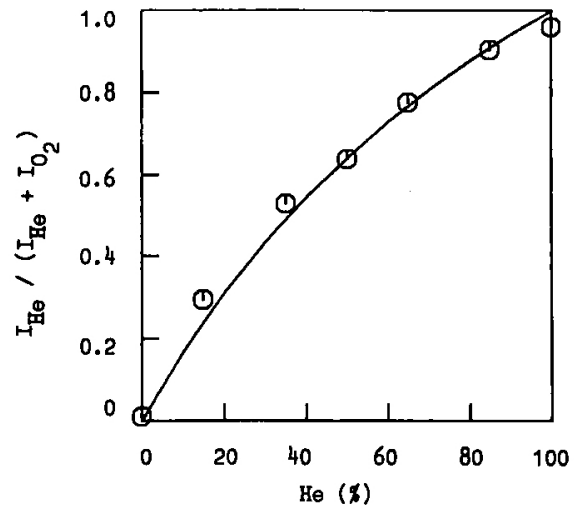

第 7 図 空気と He の混合気体に対する較正特性 
第 6 図に，較正特性が得られたときの出力波形の一 例を示す。 4 重極マスフィルタは，電極に掛ける電圧 によって特定の質量数をもつ気体粒子を選択し，その 気体粒子の粒子数に比例した出力を検出する。なお， 分析管内部は， $1.3 \times 10^{-3} \mathrm{~Pa}\left(10^{-5}\right.$ torr) 以下に保たれ る必要がある．第 7 図に得られた較正特性を示す。較 正特性を得る際には，既知のモル分率の混合気体が使 用された。この較正特性を使用して，超音速気体混合 流を形成している空気と $\mathrm{He}$ の混合状態を，He と空 気のモル分率として測定できる。

\section{4. 可視化実験}

この衝薮波風洞を使用して，超音速流相互の気体混 合流の生成状態を確認するため,シュリーレン法を用 いて可視化を行った。な扔第 4 図には、シュリーレン 写真撮影に用いられる発光用トリガーパルス波形が， 貯気槽圧力履歴，超音速流の全圧履歴（ピトー圧 $P_{02}$ ) とともに示されている．第 8 図(a)，（b)に，反射衝 擊波によって加熱された空気と $\mathrm{He}$ の超音速気体混合 流のシュリーレン写真を示す，第 8 図の (a)と (b)て は, Heのプリーナム压力が異なっている，(a)て

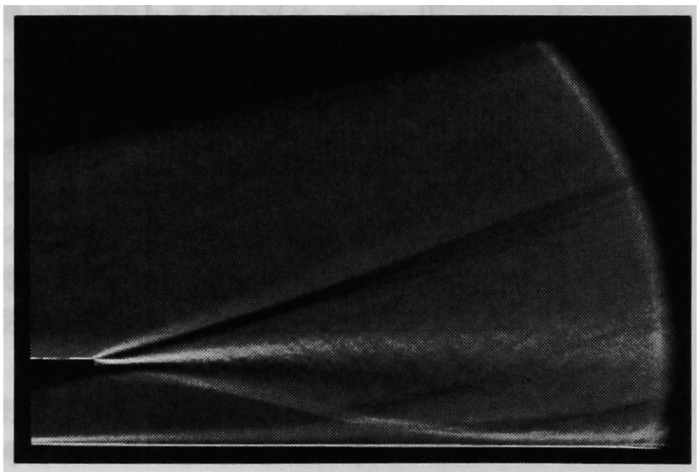

(a)

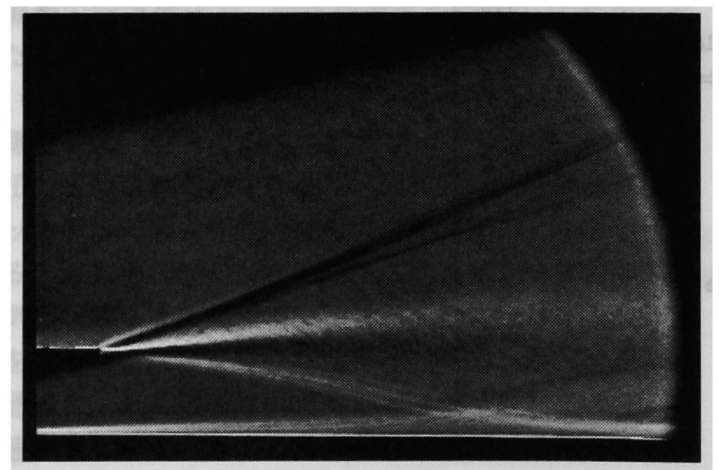

(b)

第 8 図シュリーレン写真（上：空気流、下：He 流）
は、プリーナム圧力が， $343 \mathrm{kPa}\left(3.5 \mathrm{kgf} / \mathrm{cm}^{2}\right)$ で る. (b)ては，プリーナム圧力が，588 kPa（6.0 $\mathrm{kgf} / \mathrm{cm}^{2}$ ) でる。 その他の条件は，(a)，(b)とも 等しく，以下に示すとおりである．空気側：入射衝撃 波マッ八数 $M_{\mathrm{s}}=2.0$, 眝気槽圧力 $P_{5}=196 \mathrm{kPa}(2$ $\mathrm{kgf} / \mathrm{cm}^{2}$ ), 貯気槽温度 $T_{5}=750 \mathrm{~K}$, 分離板後端部に おけるマッ八数 $M_{\mathrm{a}}=3.4$. He 側：プリーナム温度 $T_{\mathrm{OH}}=300 \mathrm{~K}$, 分離板後端部におけるマッハ数 $M_{\mathrm{H}}=$ 4.2 .

第 8 図 (a)，(b)のシュリーレン写真より，分離板 下流域に空気と Heの混合首が生成され，分稚板後端 部から，混合層の上下部に斜め衝撃波が生じているの が観察される。下部に生じた斜め锥擊波は，壁面付近 で境界層と干渉し，反射しているのが観察される．第 8 図 (a )と (b) を比較すると, Heのプリーナム圧力 は(b)のほうが高いため，(a)に比べ(b)のほうが. 混合層の中心位置が上方にあり，下側に生じた斜め衡 擊波が壁面の境界層と干涉する位置も下流側となって いる. 写真の発光時間は, 2 3 ns (Febetron 706) て あり，細かい渦が存在する乱流混合層となっているの が明確に捕えられている。

\section{5. 瀿度分布測定実験}

第 8 図 (a)と同じ実験条件下において, 高速マスサ ンプリングプローブを用いて, 分離板下流域における He と空気の壊度分布測定を行った，高速マスサンブ リングプローブを使用して銥度測定を行う際には，気 流持続時間中の気体のみを高速サンプリングバルブに よって採取できることに留意して，高速サンプリンク バルブの作動時刻を決定している，その作動開始時刻 は, 空気の超音速流開始時刻より約 $500 \mu \mathrm{s}$ 遅れた時 刻とし，高速サンプリングバルプ作動開始時刻か ら, $1.8 \sim 2.0 \mathrm{~ms}$ 間気体の採取が行われる.

第 9 図に，実際に高速マスサンプリングプローブを

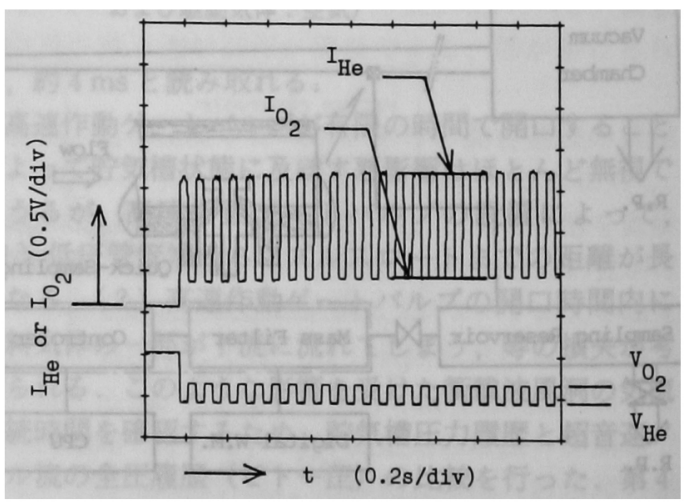

第 9 図湌度測定実験で得られた出力波形 


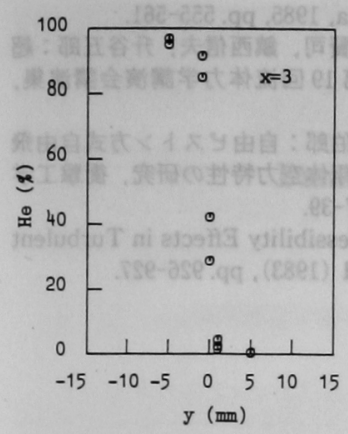

(a)

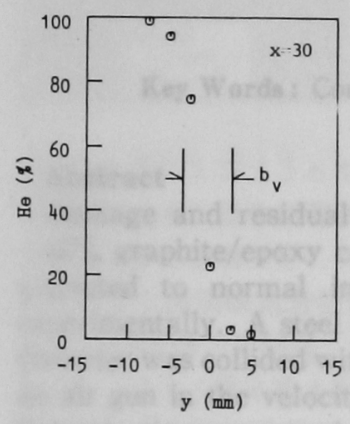

(c)

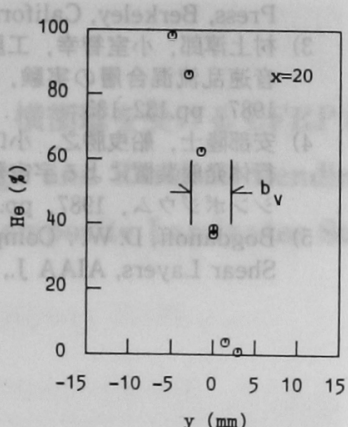

(b)

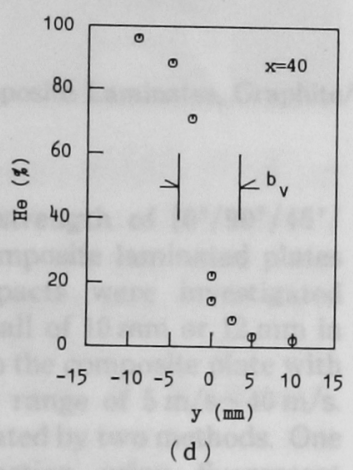

第 10 図 浱分布測定実験結果
使用して䈨度測定を行った際の 4 重極マスフィルタの 出力波形の一例を示す. $\mathrm{He}$ と空気中の $\mathrm{O}_{2}$ に対応し た電圧に対して，それぞれ $\mathrm{He} と \mathrm{O}_{2}$ の出力が検知さ れている。

濃度分布湘定結果を第 10 図 (a) （d）に示す，分 離板後端を原点とし，下流方向に $x$ 軸，垂直に $y$ 軸 を取った座標系を採用する， $x, y$ の単位は $\mathrm{mm}$ であ る. $x=3,20,30,40$ の位置において, $y$ 方向に対して 濃度分布測定を行った. $x=3$ の位置においては， -1 $<y<1$ の間において急激な濃度変化があり，He と空 気の混合層が薄い状態であるのがかかる．それに対し て $x=20,30,40$ と下流になると $y>0$ 方向において $\mathrm{He}, y<0$ 方向において $\mathrm{O}_{2}$ の割合か增し, $\mathrm{He}$ と空気 の混合層が広がっているのがわかる．また，懐度分布 の最も急唆な浱度勾配の位置は，下流になるに従っ て、, $y<0$ 方向に移動している，シュリーレン写真第 8 図(a)からも，下流になるに従って，混合層の中心 位置が $y<0$ 方向に移動していると読み取れる。

従来，気体混合層の可視発達速度 $\left(d b_{v} / d x\right) /\left(d b_{v} / d x\right)_{1}$ が. 混合層の圧縮性効果を表すパ ラメータとして用いられている $M^{+5)}, M_{\mathrm{c1}}{ }^{1}$ に対して 評価されている ${ }^{3)}$.ここで， $b_{v}$ は，可視化により得ら れる混合層の幅， $x$ は流れ方向に沿う座標である。す なわち,$d b_{v} / d x$ は流れに沿った混合首の発達率を示 すｉは非圧縮性の意味である。また， $M^{+}$と $M_{\mathrm{c} 1}$ は， 大規模構造と主流の相対的な移動マッ八数て定義さ れ，密度比 $\rho_{2} / \rho_{1}$ と速度比 $u_{2} / u_{1}$ に関連した值となっ ている、これらの比で，1は高速流側，2 は低速流側 を示す。この可視発達速度は，通常，シュリーレン写 真より判断されているが，本実験条件に扔いては， $M^{+}=0.88,\left(d b_{v} / d x\right) /\left(d b_{v} / d x\right)_{1}=1.5$ であり，他の結 果 ${ }^{1,3)}$ よりも 1.2 程度大きな值となっている。これは， ノズルがウェッジ形状であり気流が完全な平行流てな いこと，斜め衝撃波によって圧力，密度等が変化して いるなどの理由が考えられる、シュリーレン写真から 読み取れる混合領域と漲度分布を比較するため，第 10 図には、シュリーレン写真から判断される混合層 の大規模構造の領域 $\left(b_{v}\right)$ が示してある. その領域 (bv) は高速マスサンプリングプローブによって計測さ れた濃度分布のうち，㳻度変化の大きいおおよその領 域を含んでいることがわかる。

なお，衝撃波が混合層に与える影響については，き らに詳細な研究を行う予定である。

\section{6. 結 論}

（1）高速作動ゲートバルブそして高速作動ボール バルブの動作特性抢よびそれらの開口時刻と眝気槽状 態との同期の再現性は良好である。製作した高速作動 バルブ方式衝擊波風洞を用いて行った実験において， 超音速気体混合流の再現性は良好であり，本実験条件 下では作動時間が約 $3 \mathrm{~ms}$ 得られた. 高速作動バルフ 方式衝擊波風洞を使用して，超音速気体混合問題を対 象とした実験に十分使用できうることが確認された。

（2）高速サンプリンブバルブ方式を用いた高速マ スサンプリングプローブを使用して，超音速気体混合 流れ場における気体の濃度測定が十分可能であること が確認された。

（3）高速マスサンプリングプローブを用いた濃度 分布測定実験によって，空気と He の超音速混合層に おける濃度分布構造を明らかにできた。

（4）シュリーレン法による可視化実験結果と高速 マスサンプリングプローブによる濃度分布測定結果の 比較によると、シュリーレン写真から観察される混合 層の領域は，高速マスサンプリングプローブによって 測定された濃度分布のうち，濃度変化の大きなおおよ その領域を含むことが確認された。

本研究にあたり，有益な示唆を頂いた小口伯郎博 土，ならびに，実験に協力頂いた武藏工業大学学部生 の有賀浩伸君に感謝致します 


\section{参考文献}

1) Papamoschou, D. and Roshko, A.: Observations of Supersonic Free Shear Layers, AIAA Paper, 86-0162 (1986).

2) Oguchi, H., Ohue, H., Sato, S. and Funabiki, K. : SelfActing Double Shock Tubes and Application to Experi. ment of Gases Mixing Process, Proc. 15th Int. Symp. on Shock Waves and Shock Tubes, Stanford University
Press, Berkeley, California, 1985, pp. 555-561.

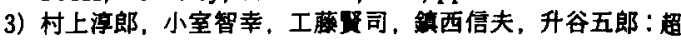

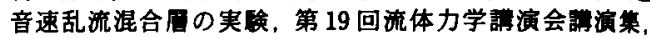
1987, pp.132-135.

4）安部隆士，船电勝之、小口伯郎：自由ピストン方式自由承 行体発射装置による宇宙飛翔体空力特性の研究，推等工 シンポジウム, 1987, pp.37-39.

5) Bogdanoff, D. W.: Compressibility Effects in Turbulent Shear Layers, AIAA J., 21 (1983), pp. 926-927. 